\title{
Role of Vaidyas and Ayurveda and Its Impact on Human Health
}

\author{
Shaifali Goyal, Rajni Negi, Prabhakar Semwal, Rahul Vikram Singh* \\ Department of Biotechnology, Graphic Era University, Dehradun, India \\ Email: ${ }^{*}$ rahul.negi121@gmail.com
}

Received 31 May 2014; revised 5 July 2014; accepted 15 August 2014

Copyright (C) 2014 by authors and OALib.

This work is licensed under the Creative Commons Attribution International License (CC BY). http://creativecommons.org/licenses/by/4.0/

(c) (i) Dpen Access

\section{Abstract}

Nowadays medicine is an essential part of daily life and it was also used in traditional life style. There are a huge number of pharmaceutical products available in the market at the present time. Among them $80 \%$ of all such pharmaceutical products derived from plant source. In the developing country viz. India, Africa, Sri Lanka, Nepal, etc. $70 \%$ of the world population are directly and indirectly depending on herbal drugs and products. Although advanced Western medicine has gained popularity in the current market, expensive cost, bacterial resistance and side effect on human body are some crucial factors, which make the western medical system less attractive for long periods. Through modern bio-technology approach, Good Manufacturing Practices (GMP) could improve the effectiveness, low cost, stability of the drug. The aim of this study is to focus on the traditional medicinal system and there is a strong need to change the scenario of the modern medical system for better health care for the long-lasting future.

\section{Keywords}

Bio-Technology, Western Medical System, India, Africa, Sri Lanka, Nepal

Subject Areas: Public Health, Translational Medicine

\section{Introduction}

Ayurveda (Sanskrit ayu-life; Veda-knowledge) is an ancient science of Indian medicines which is thousands and thousands of year's old [1]. Ayurveda, a science of our ancestors, which relied on the use of plants native to their region having medicinal properties, is losing its importance nowadays due to the dependency on western medicines. It is believed to be the natural system for improving one's health. It is native to the Indian subcontinent and the texts are included in Charak Samhita, Rigveda, Rasayna Shastra and Susrutha Samhita [2]. Right

${ }^{*}$ Corresponding author. 
from very olden days it is believed that Ayurvedic herbs are supposed to give a solution for all kinds of diseases which were even considered impossible by another field of medical science. WHO reported, 70\% of world population depending on Ayurvedic and traditional folk medicines. Nowadays many research institutes work on herbal drugs and its application for the treatment of various disorders like Alzheimer's, Cancer, Diabetes, Strok and neuro-degenerative disorders, etc. Currently in 2013-2014, BHU Professor reported a patent for AD. Ayurveda, which is considered to be a form of complementary and alternative medicine (CAM) within the western world, where several of its methods, such as the use of herbs, massage, and Yoga as exercise or alternative medicine, are applied on their own as a form of CAM treatment. The primary aim of this theme is to highlight the Ayurveda medical systems, so that people pay their attention on these schemes.

\section{Historical Role of Vaidyas and Ayurveda in Old Medical System}

Vaidyas and Ayurveda are old medical system in ancient time. Vaidyas are those peoples which have great knowledge about our traditional folk medicines. In many portions of India, Vaidya is doing his work very well; there is no need of any modern medicines. There are several examples of Ayurvedic medicine, which are given in our holy book like the Ramayana. Sanjeevani booti (Selaginella bryopteris), a great example of our past, is a pteridophytic plant which is known from the epic Ramayana to possess miraculous renascence abilities. This plant was found to be present on Sumeru mount, in the Himalayas, which was lifted up and carried away by Hanuman when Lakshman got wounded badly by Inderjeet. The magical plant is capable of curing nearly any indispositions like in heat strokes, jaundice, and etc. [3]. Since then the tribal people, called "adivasis" used the same system as their first line of defense in curing and getting rid of diseases, ranging from fever, headache, and asthma to diabetes, cancer etc.

The use of Ayurveda actually is a "prasad" of Goddess Dhanvantari, from Lord Brahma, and of our Vaidyas who focused and concentrated more on the source of the cause of the disease, unlike the western practices which tries to cure the symptoms of the illness. Either whole plants or plant parts are used to treat various diseases. For collection of the plants, there are certain rules and guidelines which are required to be followed. Like the area should be free of direct sunlight, not attacked by any pests, insects, etc., not obtained from cremation grounds, temples and sacred places [4]. But before using them in preparations, they are washed carefully in running water and shade-dried with less sunlight falling on them to avoid the rays causing harm to the plant/its parts [5]. Some examples of the preparations include the use of $50 \mathrm{~g}$ dried roots of kutaki (Picrorhiza kurroo) grinded along with 2 spoons of sugar and taken with water, used for curing fever; fresh leaves of pudina (Mentha arvensis) milled with garlic to make a paste and eaten to treat diarrhea; etc. [6]. According to Vaidyas, the amalgamation of diet, lifestyle, and medicines, have an important role in deciphering the root cause of disease and thus can be helpful in its prevention, and minor changes in them can be helpful in restoring body balance [7]. The major benefit of herbal preparations is that they bear no side-effects. Apart from using preparations, Vaidyas also emphasize on the fact of practicing chanting, rituals and song therapy, which works like a boom for healing mind. Holistic living and positive thinking also help in curing [8].

\section{Significance of Vaidyas \& Ayurveda in Modern Medicine and Current Status}

Although the current \& advanced western medicine trend is going very popular in the present time. Many previous publications proved that about $80 \%$ of all such pharmaceutical products derived from plant source. Lag phase for plant-based medicine is now quickly shifting for several reasons, issue with drug-resistant microorganisms, side effects of modern drugs and up-and-coming diseases, where no medicines are available. Apart from this, there is an important advantage in Vaidyas and Ayurveda medicine system, there is no expiry date of herbal drugs, due to this reason the stability of herbal drug is more than the synthetic drugs with no side effects on the human body. Current status indicates that more than $80 \%$ people in developing country still depend upon the traditional medical system. 30\% of worldwide sales of drugs are based on natural products [9]. According to IMS health report and WHO estimate that the global pharmaceutical market would cross the \$1.1 trillion in 2014 and present demand of medicinal plants expected to reach US \$14 billion a year and by 2050 it would be-US \$5 trillion [10]. The major point is that, by using the modern technology in Good Manufacturing Practices (GMP) in the ancient Ayurveda medicine system, so that the effectiveness, stability can be improved at lower cost. 


\section{Conclusion}

The contribution of our Vaidyas in making preparations and curing diseases is commendable. The customs which they have left behind for the new generations is invaluable. But the main problem is that due to communication gap among the youth and the Vaidyas, it failed to reach the younger generation. The reasons could be the lack of interest in understanding and knowing the importance of Vedas, the herbal preparations used to cure various diseases, and modernization of the youth, and others. Another side of the coin is that the knowledge our Vaidyas hold failed to reach us, as according to them imparting their knowhow will lead to the ineffectiveness of the preparations. They also state that their knowledge if shared and used by any individual should be for the purpose of curing and healing, and not for money making. Thus, we conclude that in today's time when new diseases are emerging like boom, there is a great need for all of us to undertake our Vaidyas knowledge to treat and prevent them before letting these diseases to gurge up.

\section{References}

[1] Wells, J.C. (2009) Longman Pronunciation Dictionary. Pearson Longman, London.

[2] Chillayah, M.M. (2013) Surgery of Susrutha Samhitha and Art of Treatment (Vaidhiya Murai).

[3] http://en.wikipedia.org/wiki/Selaginella_bryopteris

[4] Kala, C.P., Farooque, N.A. and Majila, B.S. (2005) Indigenous Knowledge and Medicinal Plants Used by Vaidyas in Uttarakhand, India. Natural Product Radiance, 4, 195-204.

[5] Semwal, D.P., Saradhi, P.P., Kala, C.P. and Sajwan, B.S. (2010) Medicinal Plants Used by Local Vaidyas in Ukhimath Block, Uttarakhand. Indian Journal of Traditional Knowledge, 9, 480-485.

[6] Phondani, P.C., Maikhuri, R.K., Rawat, L.S., Farooquee, N.A., Kala, C.P., Vishvakarma, S.C.R., Rao, K.S. and Saxena, K.G. (2010) Ethnobotanical Uses of Plants among the Bhotiya Tribal Communities of Niti Valley in Central Himalaya, India. Ethnobotany Research and Applications, 8, 233-244.

[7] http://www.ncbs.res.in/HistoryScienceSociety/IndianHealingTraditions

[8] Thatte, U.M., Rege, N.N., Phatak, S.D. and Dahanukar, S.A. (1993) The Flip Side of Ayurveda. Journal of Postgraduate Medicine, 39, 179-182.

[9] Baerheim Svendsen, A. and Scheffer, J.J. (1982) Natural Products in Therapy. Prospects, Goals and Means in Modern Research. The Pharmaceutical Journal [Sci.], 4, 93-103.

[10] Aneesh, T.P., Hisham, M., Sekhar, M.S., Madhu, M. and Deepa, T.V. (2009) International Market Scenario of Traditional Indian Herbal Drugs-India Declining. International Journal of Green Pharmacy, 3, 184-190. 